\title{
Cellular and molecular basis for thyroid cancer imaging in nuclear medicine
}

\author{
Massimo Bongiovanni • Gaetano Paone • \\ Luca Ceriani · Marc Pusztaszeri
}

Received: 10 April 2013/ Accepted: 22 May 2013/Published online: 18 June 2013

(C) Italian Association of Nuclear Medicine and Molecular Imaging 2013

\begin{abstract}
Papillary and follicular thyroid carcinomas (well-differentiated forms) are the most common follicular cell-derived thyroid malignancies, while poorly differentiated thyroid carcinomas and anaplastic thyroid carcinomas (also poorly differentiated) are the less common ones. Papillary carcinomas are morphologically and genetically different from follicular carcinomas: the former are associated, in up to $70 \%$ of cases, with $B R A F$ or $R A S$ point mutations or RET/PTC rearrangements; the latter carry the $R A S$ point mutation or the PAX8/PPARgamma rearrangement. The poorly differentiated forms have abnormalities in the TP53 and the CTNNB1 genes. The best way to image thyroid cancer cells is to exploit the capability of normal follicular thyroid cells to concentrate iodine ${ }^{131}$ I through the sodium-iodine symporter. Iodine is necessary for the production of the thyroid hormones triiodothyronine (T3) and thyroxine (T4). Unfortunately, the cells of poorly differentiated carcinomas lose the capability to concentrate iodine; at the same time, their basal metabolism increases to satisfy the energy demands of highly proliferating cells. These cells require more glucose and a glucose analog, namely ${ }^{18} \mathrm{~F}$-2-fluoro-2-deoxy-D-glucose $\left({ }^{18} \mathrm{FDG}\right)$, is used in place of glucose to study their metabolism. The increased intake of glucose is mediated by a transmembrane
\end{abstract}

\author{
M. Bongiovanni ( $\square)$ \\ Institute of Pathology, Via in Selva 24, \\ 6600 Locarno, Switzerland \\ e-mail: massimo.bongiovanni@ti.ch \\ G. Paone · L. Ceriani \\ Nuclear Medicine and Thyroid Center, IOSI, \\ Bellinzona, Switzerland \\ M. Pusztaszeri \\ Department of Pathology, HUG, Geneva, Switzerland
}

transporter called glucose transporter-1 located on the cell membrane. The alternation of ${ }^{131} \mathrm{I}$ and ${ }^{18} \mathrm{FDG}$ uptake observed in thyroid tumors and their metastases is known as the "flip-flop" phenomenon. This review looks at the cellular and molecular mechanisms underlying thyroid cancer and thyroid cancer imaging.

Keywords Thyroid · GLUT-1 - NIS $\cdot{ }^{18}$ FDG PET/CT · Well- and poorly differentiated thyroid carcinomas

\section{Introduction}

Palpable thyroid nodules are present in 4 to $7 \%$ of the general population, while nodules have been detected ultrasonographically in 50-70\% $[1,2]$. However, thyroid cancer is not one of the most common tumors: indeed, in the 2012 estimated US new cancer cases data issued by the American Cancer Society, it is ranked at fifth place in women and appears much lower down the ranking in men. Nevertheless, it has been observed that between 2000 and 2009 thyroid cancer was, of all the cancers, the one showing the highest average annual increase [3, 4]. The initial management of patients discovered to have a thyroid nodule on palpation or ultrasound examination consists of blood thyroid hormone dosage [triiodothyronine (T3) and thyroxine (T4)] followed by fine-needle aspiration (FNA) [5]. FNA is currently the most accurate, safest, and most cost-effective tool in the management of thyroid nodules [6]. Thyroid FNA cytology, being able to recognize papillary thyroid carcinomas (PTCs), is a diagnostic test for this neoplasm (Fig. 1a); conversely, it can only be used as a screening test for follicular thyroid carcinomas (FTCs), given that, in this case, it is unable to distinguish between benign lesions (nodular hyperplasia, adenomatous goiter, 


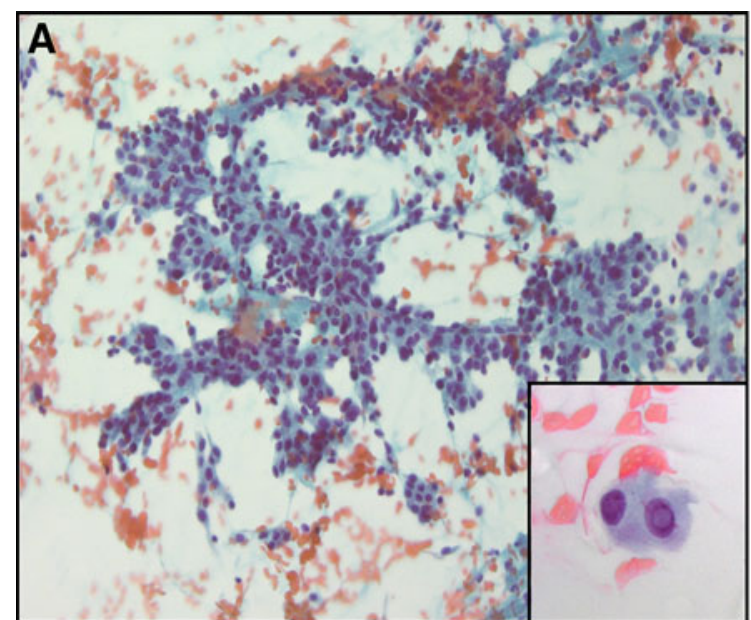

Fig. 1 Fine-needle aspiration smears of well-differentiated thyroid carcinomas. a The typical cytological appearance of papillary thyroid carcinoma with papillary structures and, inset, a nuclear pseudoinclusion. For papillary thyroid carcinoma, cytology is a diagnostic test.

or follicular adenoma) and malignant lesions (FTCs), and surgery is required for all lesions diagnosed as "indeterminate" or "follicular neoplasm" (Fig. 1b).

Primary epithelial thyroid carcinoma can be derived from the follicular cells or from the parafollicular cells, also known as C-cells, which are located around the follicles. Follicular cells are specialized to take up iodine (I) and to produce thyroid hormones (T3 and $\mathrm{T} 4$ ); C-cells produce calcitonin and are unable to take up I. In the thyroid gland, as in other organs, the more a tumor resembles the morphology and replicates the function of the corresponding organ (e.g., bile synthesis in the case of hepatocarcinoma and iodine uptake in that of follicular cell-derived thyroid carcinomas), the more well-differentiated it is considered to be. A major exception among differentiated thyroid cancers is the oncocytic variant of follicular carcinoma (Hürthle cell carcinoma), which typically does not trap iodine and does not synthesize thyroglobulin $(\mathrm{Tg})$. The capacity to take up and concentrate I has major implications for the diagnosis, follow-up, and treatment of patients with follicular cellderived thyroid carcinomas, as discussed below [7, 8]. PTCs and FTCs are well-differentiated thyroid carcinomas, while poorly differentiated ones include poorly differentiated thyroid carcinomas (PDTCs) and anaplastic thyroid carcinomas (ATCs). Thyroid tumors deriving from C-cells are known as medullary thyroid carcinomas (MTCs) and they secrete calcitonin and carcinoembryonic antigen. PTC is the most common type of thyroid cancer, followed by FTC. These two types account for $90 \%$ of all thyroid carcinomas and have a 10-year cancer-specific mortality rate of less than $10 \%$, which is among the lowest of all cancers [9]. Despite this good prognosis, the rates of local recurrence and metastasis-lymph node (for PTC) and distant (for

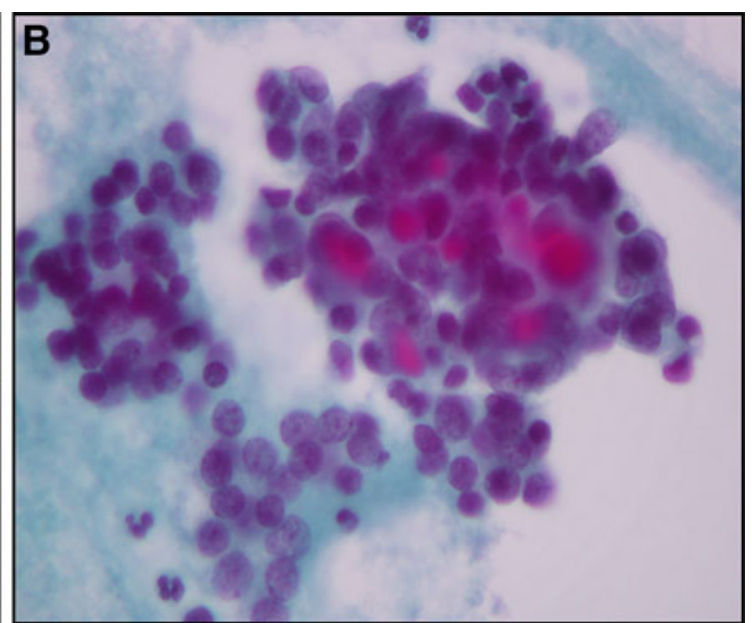

b The typical cytological aspect of a follicular-patterned lesion. For follicular lesions, cytology can only be used as a screening test

FTC) - are relatively high, thus compromising patients' quality of life $[3,10,11]$. However, the prognosis remains good, even in patients with metastases. Well-differentiated carcinomas are usually treated with initial surgery and subsequent adjunctive radioiodine $\left({ }^{131} \mathrm{I}\right)$ therapy and lifelong thyroid hormone replacement therapy. The poorly differentiated forms are instead characterized by a more severe prognosis and an aggressive course: indeed, PDTCs are also treated surgically, but adjunctive ${ }^{131} \mathrm{I}$ therapy is less effective. In ATCs, which are highly lethal (median survival between 3 and 6 months), neither surgery nor adjunctive ${ }^{131}$ I therapy are adequate. MTCs account for up to $7 \%$ of thyroid malignancies and carry a more dismal prognosis compared with PTCs and FTCs; MTCs are initially treated with surgery and lymph node neck dissection, but ${ }^{131} \mathrm{I}$ is not

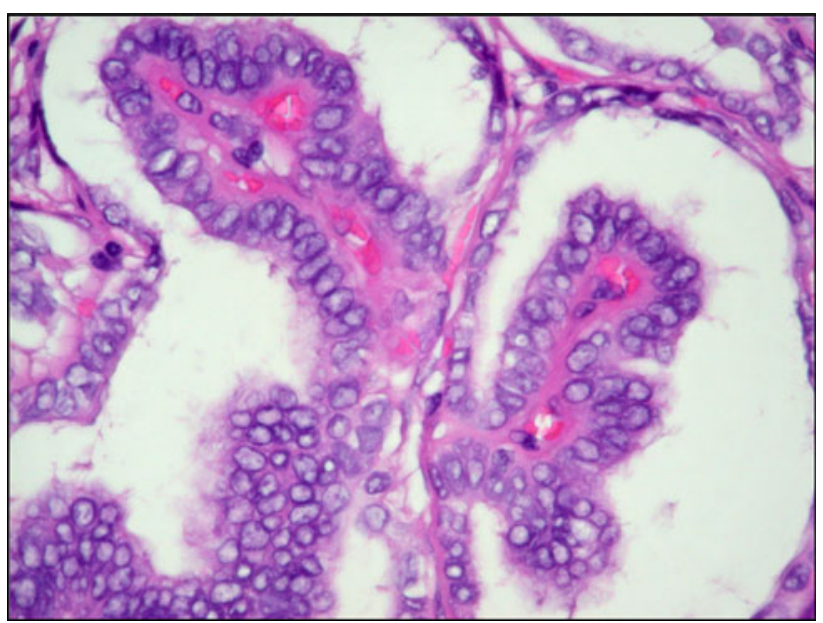

Fig. 2 Histology of papillary thyroid carcinoma with papillae, nuclear superposition, and chromatin clearing 


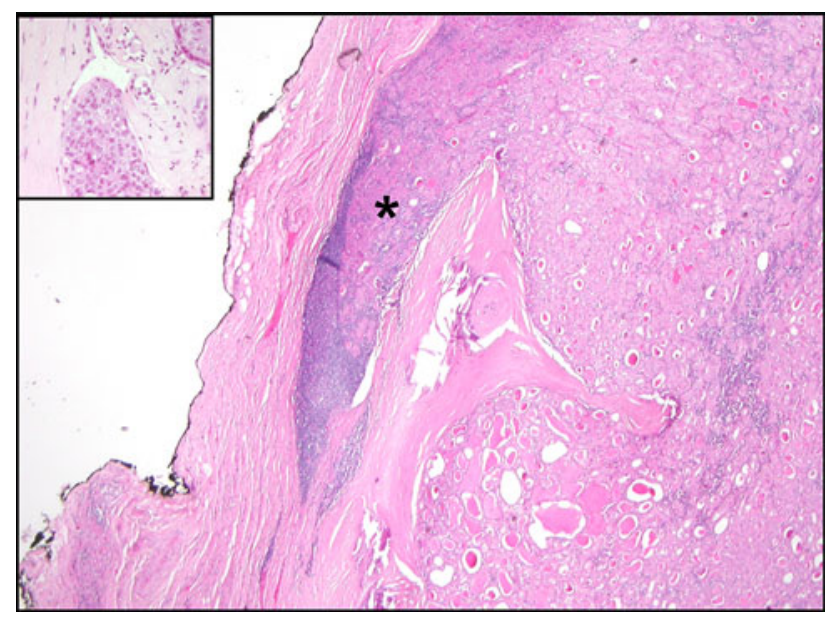

Fig. 3 Histology of follicular thyroid carcinoma with capsular invasion (*) through the fibrous capsule and, inset, vascular invasion

an option because of the different origin and function of the C-cells.

\section{Pathology in epithelial thyroid tumors}

PTC is characterized by several specific architectural and cytological features. Architecturally, the neoplastic cells are arranged in papillae each consisting of a central fibrovascular core covered by peculiar follicular cells (Fig. 2). These papillary structures can be more or less well developed, the more developed ones showing a complex branching pattern. Areas with a more typical follicular-type architecture can be variably admixed with areas characterized by these papillary structures. Cytologically, the cells covering the fibrovascular core are superposed, elongated, and cuboid, and contain variable amounts of cytoplasm. The peculiar cytological features, on the other hand, consist of a mixture of the following: nuclear pseudoinclusions (Orphan Annie eyes), which are actually invaginations of the cytoplasm into the nucleus that make the nucleus appear empty; nuclear grooves, i.e., areas of longitudinal infolding of the nuclear membrane; and chromatin clearing, i.e., margination of the chromatin at the periphery of the nucleus. Other characteristic morphological features that can be found in PTC, and are helpful for diagnosis, are psammoma bodies (calcified papillae with concentric lamellations) and multinucleated giant cells.

Unlike PTC, FTC is not characterized by any peculiar architectural or cytological features. In fact, these tumors are usually made up of small follicular structures that contain, in the center, variable amounts of colloid surrounded by normal-looking follicular cells, such as those of a non-neoplastic thyroid. Usually FTC nodules are surrounded by a fibrous capsule (as in follicular adenomas),

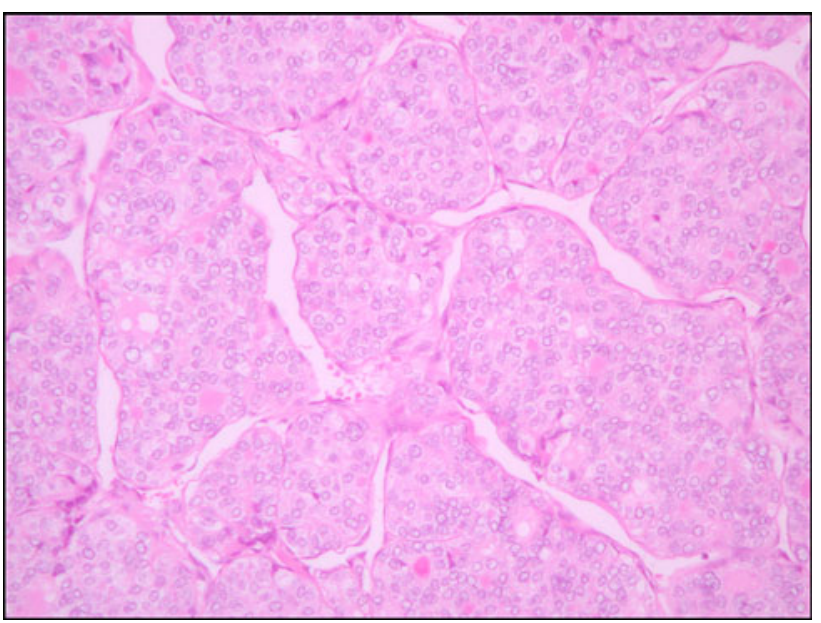

Fig. 4 Histology of poorly differentiated thyroid carcinoma with typical insular structures surrounded by capillaries

which can be variably thickened. The elements that need to be present for a diagnosis of carcinoma in an otherwise follicular-patterned lesion are: capsular and/or vascular invasion, which will indicate a follicular carcinoma or most of the above-described nuclear atypia, which will point to a follicular variant of PTC. Capsular invasion is defined as the presence of follicular structures herniating or infiltrating throughout the capsule into the surrounding thyroid parenchyma (Fig. 3). Vascular invasion is defined as the presence of neoplastic emboli composed of follicular cells and surrounded by endothelium in a vessel in the capsule of the follicular proliferation (Fig. 3, inset). Either capsular or vascular invasion (or both) is necessary for a diagnosis of FTC. According to the extent of capsular involvement (i.e., limited foci or massive extra thyroidal invasion) and vascular involvement (some vessels involved or massive vascular invasion), FTCs are further classified as minimally invasive or widely invasive. Minimally invasive FTC has an excellent prognosis; widely invasive FTC is more aggressive.

PDTCs can arise de novo or originate from a preexisting PTC or FTC and are defined as malignant follicular tumors with high-grade features (necrosis and/or mitosis) (Fig. 4). These tumors are also known as "insular carcinomas" as they have a peculiar insular architecture (solid nest of follicular cells surrounded by small capillaries); however, it is also possible to observe other architectures, such as trabecular or solid ones.

ATCs constitute the most dedifferentiated form of follicular-derived thyroid tumors and, as such, have lost all morphological and phenotypical resemblance to the normal thyroid. Like PDTCs, they can arise de novo or originate from a transformation of a well-differentiated thyroid carcinoma, and they usually present with 

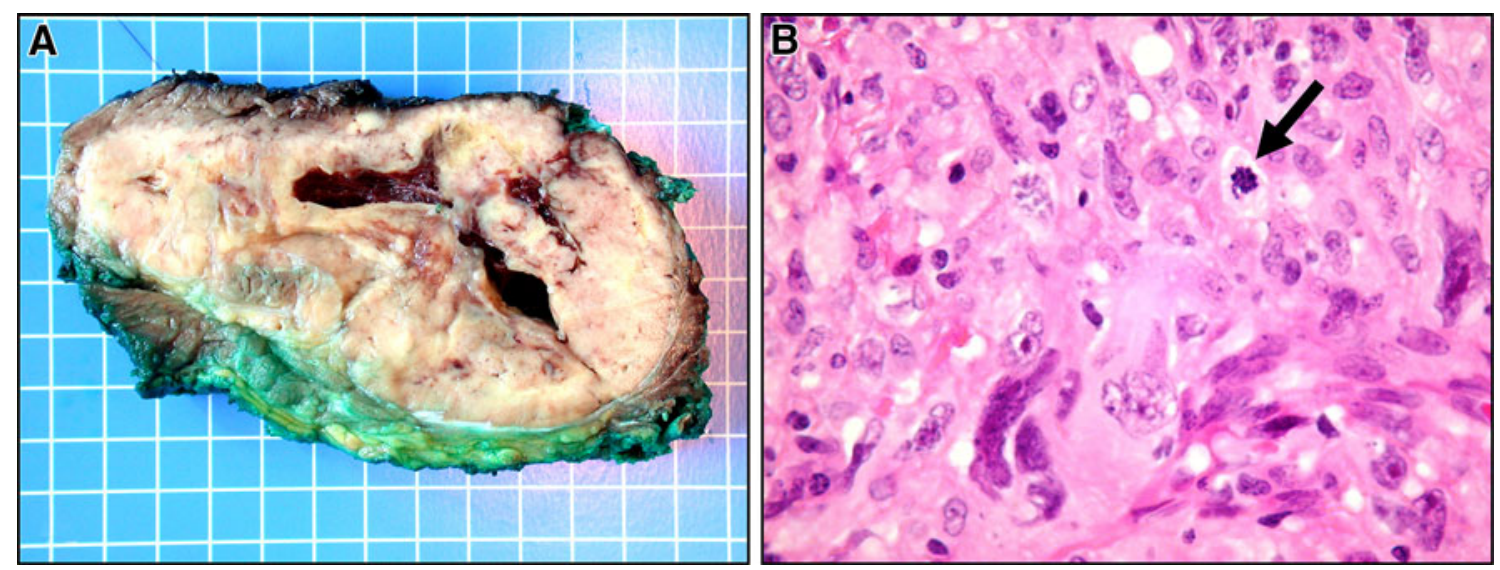

Fig. 5 Anaplastic thyroid carcinoma. a The gross appearance is usually that of an aggressive tumor with central necrosis and extra thyroidal involvement. b On histology, cells are highly atypical with spindle and giant forms and mitosis (arrow)

Fig. 6 The known genetic alterations involved in the genesis of differentiated thyroid carcinomas (PTC/FTC), poorly differentiated thyroid carcinomas (PDTC and ATC), and in medullary thyroid carcinoma (MTC)

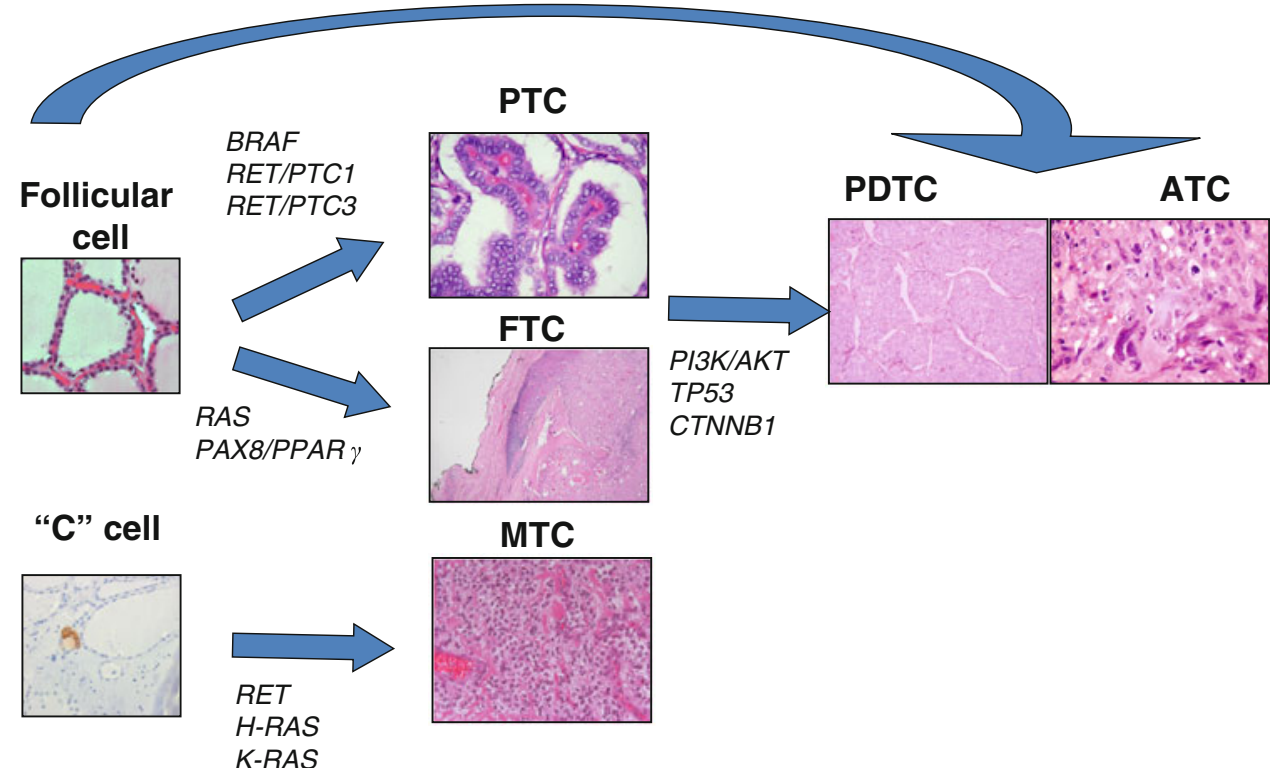

extrathyroidal invasion and distant metastasis (Fig. 5). The cells have a variable morphology: giant, spindle, pleomorphic, or squamoid. It is not unusual to encounter an ATC with a different cellular morphology, resembling a carcinosarcoma. A high mitotic index, i.e., abundant mitosis, atypical mitosis, and necrosis are the typical hallmarks of the lesion. A differential diagnosis versus metastatic disease to the thyroid should always be considered. Since this is an extremely dedifferentiated form of carcinoma, thyroid immunohistochemical markers (Tg primarily) are usually negative. Staining for epithelial markers such as wide-spectrum keratin, to detect residual or focal disease, can be useful in the differential diagnosis versus sarcomas.
The genetics of epithelial thyroid tumors

Despite originating from the same follicular cells, PTCs and FTCs show different pathogenetic mechanisms, and different genes are implicated in their development. Instead, MTCs follow a pathogenetic pathway different from the one followed by follicular cell-derived tumors (Fig. 6).

Papillary thyroid carcinomas are associated with three distinct molecular alterations: point mutations in the $B R A F$ and RAS genes and RET/PTC rearrangements. Taken together, these mutations are present in up to $70 \%$ of PTC cases, the BRAF mutation being the most common (40-45\% of thyroid carcinomas). All these alterations, which are mutually exclusive, act by triggering the 
A BRAF mut V600E (exon 15)
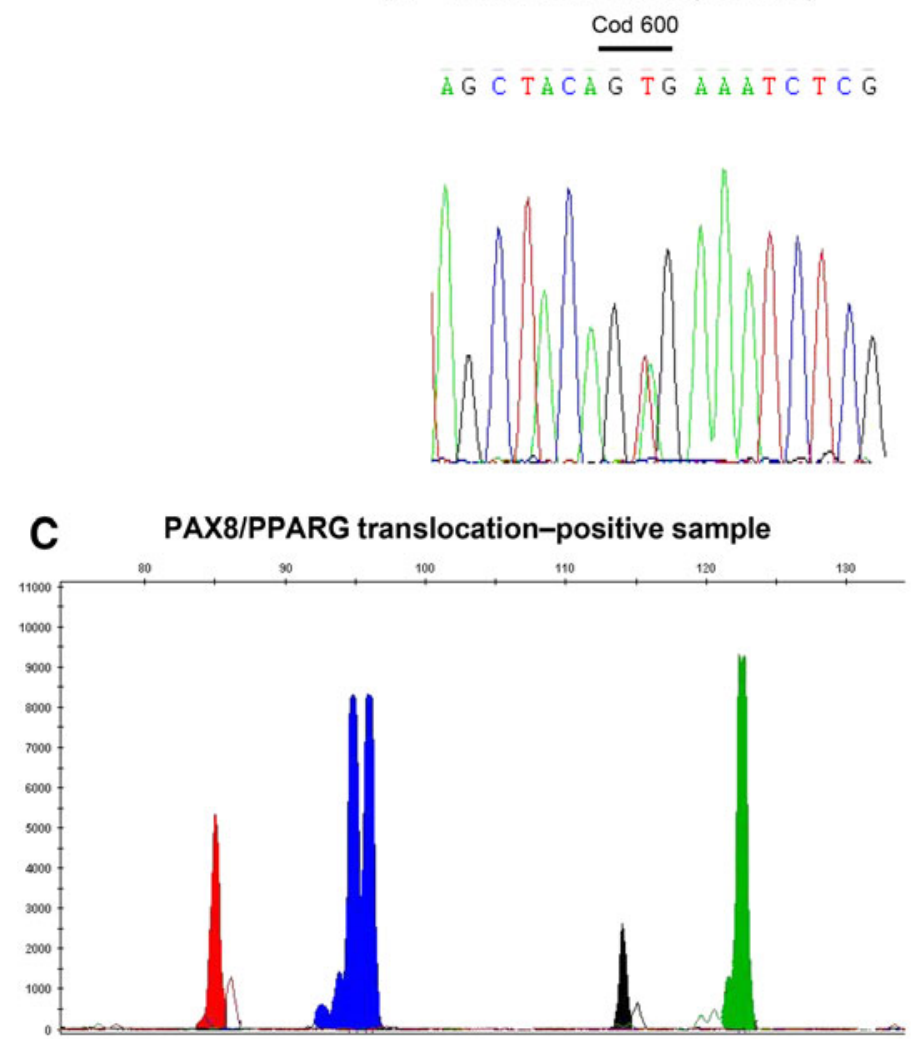

B
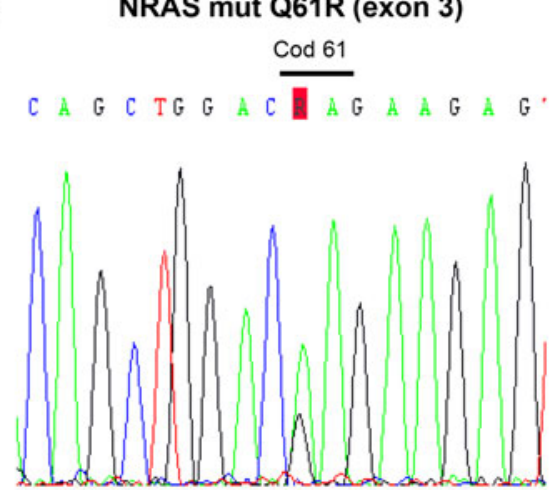

D

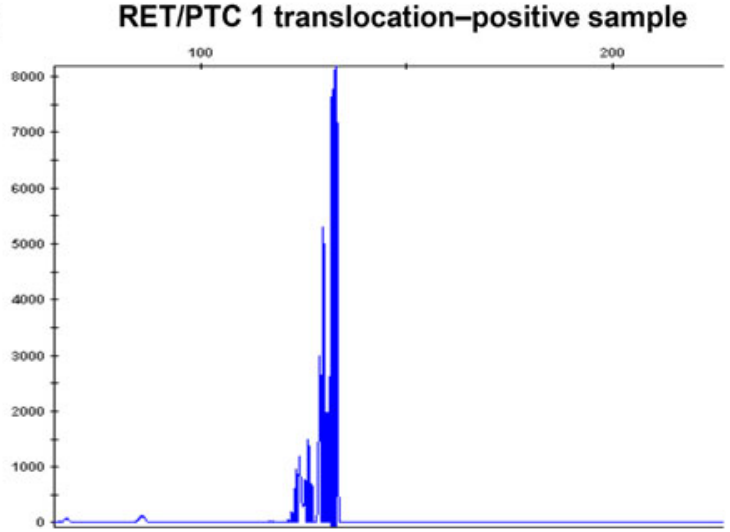

Fig. 7 An example of mutation and translocation in the main genes involved in development of thyroid carcinomas. a Representative example of the BRAF V600E mutation in exon 15. b Representative example of the NRAS Q61R mutation in exon 3. c Fragment analysis of the PAX8/PPARG translocation: presence of three different transcripts of the fusion gene: red peak, fusion of PAX8 exons 1-8

mitogen-activated protein kinase (MAPK) [12] cascade [13]. BRAF point mutations involve, in the vast majority of cases, residue 600 (V600E) and, to a lesser extent, residue 601 (K601E); RET/PTC rearrangements are numerous, but the most common are RET/PTCl and RET/PTC3. Both $B R A F$ and $R E T / P T C$ are highly specific, being found only in PTCs and not in benign lesions [13]; conversely, $R A S$ point mutations usually involving codons 12,13 , and 61 of the three $R A S$ genes $(H, K$, and $N)$ can also be found in up to $40 \%$ of follicular thyroid adenomas (FTAs). The most common mutations involve codon 61 of the NRAS and KRAS genes.

Patients with FTCs commonly harbor $R A S$ point mutations or the PAX8/PPARgamma rearrangement. Taken together, these mutations, which are mutually exclusive, are present in up to $75 \%$ of FTC cases (RAS point mutations in $30-50 \%$ and the PAX8/PPARgamma rearrangement in $30-40 \%$ ) [13]. RAS point mutations can also be to PPARG exon 1; blue peak, fusion of PAX8 exons 1-10 to PPARG exon 1; black peak, fusion of PAX8 exons 1-8 plus exon 10 to PPARG exon 1; green peak, positive control PAX8. d Fragment analysis of the RET/PTC translocation: presence of the rearrangement form RET/PTC 1 (blue peak, fusion of CCDC6 exon 1 to RET exon 12) (color figure online)

present in FTAs, while the PAX8/PPARgamma rearrangement is found in less than $5 \%$ of FTA cases, which, for this reason, are considered to be at high risk of developing FTC in the future.

It is thought that PDTCs and ATCs can either derive from PTCs and/or FTCs or develop ex novo. Consequently, they can show alterations typically found in well-differentiated carcinomas and others that are considered to be more specific. The latter includes genetic alterations involved in the $P I 3 K / A K T$ pathway and alterations of the TP53 and CTNNB1 genes [13].

The above genetic alterations are actually used in the pre-surgical setting in patients with indeterminate FNA cytology results, in whom they are tested for either singly or in a panel. In cases with a cytological diagnosis of "follicular neoplasm", the finding of any mutations in the BRAF, RAS, RET/PTC, and PAX8/PPARgamma genes increased the cancer risk from $14 \%$ (in case of negative 
Fig. 8 Nuclear imaging of follicular thyroid cell: molecular basis (abbreviations: see text)

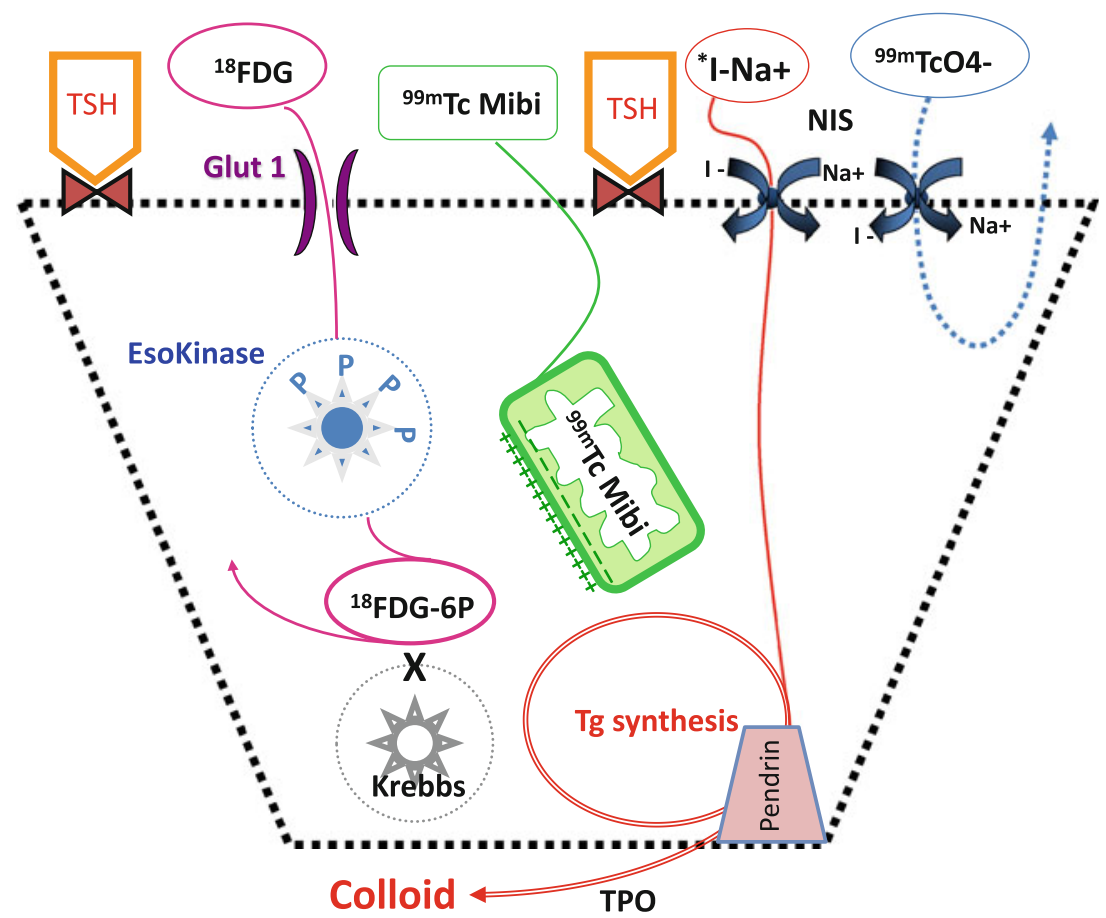

mutational test) to $87 \%$, prompting surgical resection of the entire thyroid [13, 14] (Fig. 7).

How should thyroid cancer cells be imaged?

\section{Sodium-iodide symporter (NIS)}

A unique characteristic of normal thyroid tissue is the capability of its follicular cells to take up and process I to synthesize the thyroid hormones $\mathrm{T} 3$ and $\mathrm{T} 4$, which are composed of 3 and 4 atoms of I, respectively, and are secondarily incorporated into Tg (Fig. 8). The uptake of I into follicular cells is regulated by the sodium-iodide symporter (NIS). The NIS is a transmembrane protein that carries sodium and iodine from the blood into the follicular cells: $\mathrm{I}$ is then concentrated in the colloid and sodium is expelled from the cells by the sodium pump [15-17]. The NIS, located in the basolateral membrane of the follicular cells, is termed a symporter because the two molecules are carried in the same direction, one being transported down and the other against a concentration gradient. The NIS mechanism represents the basis for the use of ${ }^{131} \mathrm{I}$ for diagnostic and therapeutic purposes, because ${ }^{131} \mathrm{I}$ can be concentrated in exactly the same way as I and is regulated by thyroid stimulating hormone (TSH) [18]. Two other transmembrane proteins called pendrin and apical $\mathrm{I}^{-}$ transporter, located on the opposite apical (luminal) part of the follicular cells, draw I into the lumen of the follicles ("efflux"), where thyroid peroxidase is responsible for incorporating it into Tg ("organification") [19]. The NIS protein is not expressed exclusively in the thyroid, but also in the striated duct cells of the salivary glands-this explains the uptake of I by these glands and therefore some of the side effects of ${ }^{131}$ I therapy [18] —and in other organs too $[18,19]$. The liver is physiologically the most important organ for the metabolism of thyroid hormones and $\mathrm{Tg}$. The widespread hepatic uptake that can sometimes be observed on ${ }^{131}$ I whole-body scanning (WBS) may be interpreted as an expression of metabolism of radioiodinated thyroid hormones (in patients with remnant thyroid tissue) or as an expression of radioiodinated $\mathrm{Tg}$ released from functioning cancer tissue (in patients without remnant thyroid). On this basis, some authors take hepatic uptake visualized on WBS to be an indirect finding of suspicious residual DTC even in the absence of clear pathological extra-hepatic sites of disease. Other authors instead support the theory that there is no direct correlation between serum $\mathrm{Tg}$ evidence of metastasis and hepatic ${ }^{131} \mathrm{I}$ uptake, suggesting that the latter finding is explained by the presence of multiple metabolic factors such as alterations of lipoproteins and liver enzymes that lead to an increased radioiodine uptake [20-22]. The NIS is fully expressed by normal follicular cells and its activity is stimulated by TSH, which is responsible for NIS transcription, biosynthesis, and regulation at plasma membrane level [19]. This is why WBS is used in combination with TSH stimulation, achieved either indirectly by the withdrawal of the replacement treatment with thyroxine or directly by administration of exogenous thyrotropin.

Unfortunately, carcinogenesis disrupts the regulatory growth mechanism and causes cells to lose their differentiation. The more undifferentiated they become, the more 
the follicular cells lose their ability to express the NIS (both because of dysregulation of the NIS gene, including promoter methylation, and because of incorrect localization of the NIS protein in the membrane) [23]. However, the molecular basis of this loss of function is not well-known, and the $p 53$ mutation is the only a genetic change that has been clearly shown to correlate with poor differentiation. Some recent studies demonstrated a significant correlation between the presence of the BRAF mutation and a worse outcome of differentiated thyroid carcinoma [24]. However, the molecular processes linking this mutation with dedifferentiation processes are still unknown, even though stimulation of MAPK signaling seems to play an important role. Similar data have also been shown for loss of function of TC metastases during tumor progression [24]. The loss of NIS expression is functionally demonstrated by the reduced ability of thyroid cancer cells to concentrate I. Consequently, radioiodine therapy has limited or no value in treating undifferentiated non-iodine-avid carcinomas.

Recent years have seen several therapeutic attempts to redifferentiate thyroid cancer and reverse the loss of NIS expression, with controversial results. Retinoic acids and active vitamin A metabolites showed promising experimental results in the redifferentiation of non-radioiodineavid thyroid cancer. Indeed, in recent in vitro studies retinoids induced several redifferentiating effects on thyroid carcinoma cell lines, as suggested by increased expression of NIS mRNA, type I iodothyronine deiodinase and alkaline phosphatase, inhibition of cellular growth, and increased cellular radioiodine uptake $[25,26]$. The results of a few early clinical pilot trials confirmed that retinoic acids may restore radioiodine uptake and decrease tumor size [27, 28]. However, subsequent clinical studies have shown that I uptake can be restimulated after 13-cis-retinoic acid treatment in only about $20-50 \%$ of patients with radioiodine non-responsive thyroid carcinoma. Nevertheless, this redifferentiation effect shown by induction of radioiodine uptake is frequently temporary and does not always seem to translate into significant clinical benefits [29-31]. Recent studies have documented a significant role of increased MAPK activity due to gene mutations (in particular of $B R A F$ ) in the dedifferentiation of the thyroid tumor cells. In vitro studies in transgenic mice in which mutant $B R A F$ is expressed showed that when BRAF activation is switched off genetically or inhibited with targeted kinase inhibitors, the tumor cells regain the ability to trap radioiodine. These preclinical observations provided the rationale for clinical studies in which patients with radioiodine-refractory TC were treated with this group of drugs. In a recent study, Ho et al. studied the impact of selumetinib (MAPK inhibitor) in restoring the ability to capture iodine and, therefore, the effectiveness of ${ }^{131} \mathrm{I}$ therapy in patients with radioiodine-refractory dedifferentiated thyroid cancer [32]. The encouraging preliminary results seem to provide clinical confirmation of the in vitro model even though the effect appeared to be greater in patients with $R A S$-mutant than $B R A F$-mutant disease. NIS gene transfer has been suggested as a novel treatment modality for several cancers that lack NIS expression [33]. However, this type of therapy has limited effects and can produce serious adverse radioiodine dose-related side effects [34]. Because of its efficient iodine uptake function, the NIS has been exploited for imaging normal thyroid tissue or differentiated thyroid carcinoma with ${ }^{123} \mathrm{I}$ and ${ }^{124} \mathrm{I}$ as well as for ${ }^{131}$ I treatment of differentiated thyroid carcinomas and their metastases. However, while uptake of I is related to NIS expression and concentration, its retention is influenced by the activation of the metabolic pathways of $\mathrm{Tg}$ synthesis and iodination, and this explains why TSH stimulation (either through withdrawal of $\mathrm{T} 4$ therapy or through alpha thyrotropin injection) to stimulate the metabolism of thyroid cancer cells is both necessary and opportune. On the other hand, thyroid uptake of $99 \mathrm{mTc}$ pertechnetate (99mTcO4-) is related only to NIS expression, as this anion is not a substrate for any metabolic pathway: in fact, its retention in the thyroid cells is temporary, with complete washout occurring within about $30 \mathrm{~min}$. These characteristics allow I radioisotopes to be replaced with $99 \mathrm{mTcO} 4-$ for functional thyroid imaging, sparing significant irradiation of the parenchyma.

Nevertheless, the uptake of all these tracers is strictly related to the plasmatic concentration of stable I. In fact, the intake of large amounts of I through diet, I-rich drug treatments (e.g., amiodarone), or iodinated contrast media may render ineffective any functional imaging and basically make metabolic radiotherapy with radioiodine impossible. Therefore, a careful history and determination of plasma iodine are the essential tools for planning diagnostic work-up and therapy of thyroid cancer.

99mTc-methoxyisobutyl isonitrile (MIBI) has been reported to show considerable clinical utility in the study of many carcinomas, being one of the most widely used oncotropic radiotracers. MIBI is a lipophilic cation that crosses the cell membrane and penetrates reversibly into the cytoplasm via thermodynamic driving forces and then, thanks to a different electrical gradient regulated by a high negative inner membrane potential, irreversibly crosses the mitochondrial membrane [35]. Cancer cells, with their increased metabolic turnover, are characterized by a higher electrical gradient of the mitochondrial membrane, and thus show an increased accumulation of sestamibi compared to normal cells. Differentiated thyroid carcinoma 
shows uptake and persistent retention of MIBI. This is particularly true of oncocytic (Hürtle cell) tumors [36]. These tumors were initially regarded as a variant of FC, then as an independent form of different origin [37, 38], and then once again as a morphological variant of neoplasms derived from follicular cells (papillary and follicular) $[39,40]$. There have also been different opinions on the aggressiveness of oncocytic (Hürtle cell) tumors, with some considering these neoplasms more aggressive than conventional carcinoma types and thus to require total thyroidectomy [41] and others comparing them to classical follicular neoplasms, with a behavior that can be predicted on the basis of well-defined histopathological criteria [38, 42-45].

The main value of MIBI imaging in the management of differentiated thyroid carcinomas lies in the fact that it may complement the use of ${ }^{131}$ I WBS in determining the extent of locoregional and distant disease, being able to identify both positive I lesions (even small ones due to the use of the SPET technique) and negative I metastases linked to more aggressive subtypes, such as Hürtle cell carcinoma, tall cell and insular carcinoma, or cases of metastatic papillary and follicular carcinomas undergoing dedifferentiation with the simultaneous loss of the ability to capture iodine [46]. Several studies have also revealed a direct correlation between the degree of MIBI retention in tumor cells and the expression of the multi-drug resistance (MDR) gene, using MIBI imaging for phenotypic assessment of MDR [47]. The lipophilic cation has been shown to be a substrate for $P$-glycoprotein ( $p$-gp) encoded by the MDR gene. This $p$-gp determines an efflux pump that prevents the outflow from the tumor cell of a series of cytotoxic drugs (doxorubicin, etoposide, vincristine, and others) and simultaneously of a series of substrates, such as MIBI. According to this theory, patients with tumors that do not concentrate MIBI seem to be more likely to be nonresponders to chemotherapy. Another correlation was found between tumor cell uptake of MIBI and the expression of bcl-2, a family of proteins that regulate the cell apoptosis cascade. Apoptosis is a fundamental step in the chain reaction activated by chemotherapy. In particular, the increased permeability of the mitochondrial membrane, which appears to be a fundamental step in the apoptotic process, depends on the expression of these anti-apoptotic proteins which prevent permeabilization of the mitochondrial membrane, with a consequent absence of MIBI intracellular uptake [35]. These phenomena support the theory that enhanced MIBI clearance depends on the presence of the MDR protein and mitochondrial protein bcl-2, and therefore that MIBI imaging may be an appropriate tool for predicting the development of MDR and subsequent treatment failure. Although several studies confirmed these data mainly in breast cancer, myeloma, and lung cancer; there is still no clear evidence of these mechanisms in thyroid cancer.

\section{Glucose transporter (GLUT)}

Several studies have demonstrated the usefulness of glucose transporter 1 (GLUT-1) immunohistochemistry in the evaluation of neoplastic cell metabolism [48, 49]. In 2002, Schönberger et al. [50] suggested that overexpression of GLUT-1 on the cell membrane was directly correlated with a greater biological aggressiveness of thyroid cancer. Cell membrane expression is usually evaluated because this is where GLUT-1 transporters are localized. GLUT-1 was shown to be expressed in $0-10 \%$ of follicular adenoma, $52.9-100 \%$ of PTC, 33.3-58.8 \% of FTC, $80 \%$ of PDTC, and almost all ATC cases [49]. The same variability of expression was shown in other tumor types, e.g., ranging from 30 to $100 \%$ in studies dealing with breast cancer. GLUT-1 expression has been found to positively correlate with the degree of differentiation of thyroid tumors, being more intensively expressed in ATCs than in well-differentiated forms [48, 49, 51-53]. Moreover, GLUT-1 expression has been found to positively correlate with the proliferative index, as can intuitively be expected [49]. Positron emission tomography (PET) can be used to evaluate cellular glucose metabolism [8, 49, 54-56] using a glucose analog, namely ${ }^{18} \mathrm{~F}$-2-fluoro-2-deoxy-D-glucose $\left({ }^{18} \mathrm{FDG}\right)$, which thanks the attachment of a radioactive tracer, it is possible to trace. Glucose and FDG are transported through the blood circulation to the entire body and also to the tumor site, where they are distributed to tumor cells along with other blood nutrients. Thanks to the typically well-developed vascular network of tumors, they can reach all tumor cells and, by means of selective and specific transporters, diffuse into the cells [57]. The most well known of these is the insulin-independent transmembrane protein GLUT-1, also known as solute carrier family 2 (facilitated glucose transporter), member 1 (SLC2A1). GLUT-1, or SLC2A1, is encoded by the SLC2A1 gene, located on chromosome 1p34.2. Having entered the cells and before entering the glycolysis pathway, glucose and FDG undergo a further regulatory step, i.e., they are phosphorylated, by intracellular kinases, to become glucose-6-phosphate. Glucose then follows the glycolysis pathway, while FDG is not further degraded. Neoangiogenesis, which is upregulated in cancer cells, is necessary to carry glucose and oxygen to cells. Furthermore, glucose metabolism, transmembrane transport, and phosphorylation of glucose are also upregulated in cancer cells [58]. In particular, an overexpression of some enzymes of the glycolysis pathway, in particular, the isoenzymes hexokinase I and 2 (HK1 and HK2), has been shown to be the main cause of the increased metabolic rate. Bos et al. 
showed that glucose uptake by breast cancer cells is also related to proliferation rate, tumor cell density, and the presence of necrosis, lymphocytes, and angiogenesis [48]. Along the same lines, ${ }^{18}$ FDG uptake follows GLUT-1 immunohistochemical expression, with more avidity (and more expression) being shown by dedifferentiated thyroid tumors. A strong positive correlation has been shown between the presence of GLUT-1 and ${ }^{18}$ FDG uptake [48], although cytoplasmic staining does not allow this correlation to be demonstrated [48, 52]. Immunohistochemical identification of the presence of GLUT-1 should be a negative prognostic factor making FDG PET a technique of great interest for identifying high-risk patients. Hooft et al. in 2005 reported that in addition to the GLUT expression, patients with positive FDG PET for metastasis of thyroid cancer also showed an overexpression of hexokinase I resulting in increased phosphorylation of intracellular glucose, which was reflected in an increased FDG uptake on PET imaging [59]. Because most cancers overexpress cell membrane GLUT transporters, especially GLUT-1, and have enhanced hexokinase activity, ${ }^{18} \mathrm{FDG}$ is transported and remains trapped in the cancer cells. The final quantity of the tracer is directly related to several factors: vascularization, the amount of GLUT-1, the hexokinase activity, the proliferation rate, and the expression of the hypoxia-inducible factor that regulates the expression of GLUT. The expression of GLUT-1 and hexokinase in thyroid tumors has been shown to be an index of aggressiveness and loss of tumor differentiation. Conversely, well-differentiated tumors (follicular and papillary) have heterogeneous and often poor GLUT-1 expression.

The thyroid cancers characterized by higher levels of FDG uptake are the poorly differentiated forms, PDTC and ATC, the tall cell variant of PTC, and BRAF-mutated papillary cancer [60], showing the above expression of GLUT-1 and enhanced rate of hexokinase I. Other, different clinical factors may affect the sensitivity of PET imaging, such as the histological variant, the degree of differentiation, and the presence of genetic mutations $(B R A F)$, as well as the rate of $\mathrm{Tg}$ and the anatomical site of metastasis.

In recent years, PET imaging with ${ }^{18} \mathrm{FDG}$ has been shown to be effective in the management of patients with differentiated thyroid carcinoma, especially the PDTC and ATC forms. In particular, the use of hybrid PET/CT scanning has reduced the number of false positive and inconclusive findings and increased the identification of FDG-negative lesions [61-63]. Positron annihilation is the phenomenon providing the basis of PET imaging. Positrons cover a short distance in tissues before encountering an electron. These particles annihilate one another, emitting a pair of 'anti-coincident' $\gamma$ photons with an energy level of $511 \mathrm{keV}$. Anti-coincident photons are detected in a PET detection ring (i.e., coincidence counting), and those reaching the detector in temporal pairs (i.e., few nanoseconds shift is allowed) are used to provide images by iterative algorithms. Attenuation is corrected using an external 68Ge source or CT. Today, hybrid PET/CT scanners are generally used and attenuation correction is performed by the CT part of the scanner. This also provides anatomical images that serve as a roadmap for functional PET images. The main advantage of this imaging modality is its ability to quantify the uptake of tumor tissue and express it through a semiquantitative index [64]. This quantification provides information about tumor mass, but is also extremely useful for following the metabolic changes over time and for monitoring therapy response. Imaging with ${ }^{18} \mathrm{FDG}$ is an established tool in the diagnosis, management, and follow-up of many solid tumors. The most common positron-emitting tracers applicable to differentiated thyroid cancers are ${ }^{18} \mathrm{FDG}$ (half-life $110 \mathrm{~min}$ ) and ${ }^{124} \mathrm{I}$ (half-life 4.2 days). As seen, ${ }^{18} \mathrm{FDG}$ behaves as an analog of glucose and is trapped by and remains in cancer cells [65]. ${ }^{124} \mathrm{I}$ is a positron-emitting iodine isotope. The sodium-iodide symporter is composed of 643 amino acids and is located in the basolateral compartment of the follicular cells, close to the capillaries. Iodine uptake is directly correlated with the presence of this membrane transporter protein.

${ }^{18}$ FDG PET/CT imaging in differentiated thyroid cancers currently plays its most important role in cases of recurrent disease with increased $\mathrm{Tg}$ and negative US and diagnostic whole-body scan. Normal thyroid tissue takes up little FDG and the same applies to well-differentiated tumors. The increased FDG uptake in thyroid cells compared to the reduced iodine distribution is linked to an initial dedifferentiation of cancer cells [49]. The Tg level also influences the sensitivity of PET imaging. Many studies have reported an increased sensitivity that was directly proportional to the increase of $\mathrm{Tg}$. The American Thyroid Association (ATA) guidelines recommend performing ${ }^{18}$ FDG PET/CT when an empirical activity of ${ }^{131} \mathrm{I}$ fails to localize foci of persistent or recurrent disease, and the unstimulated serum Tg level exceeds $10 \mathrm{ng} / \mathrm{ml}$ [66]. In recent years, several groups have shown good sensitivity and specificity of the method also for cases with $\mathrm{Tg}$ values lower than $10 \mathrm{ng} / \mathrm{ml}[67,68]$. From the perspective of the selection of patients for PET-CT scanning, these results deserve greater attention as they suggest, unlike what is recommended by the ATA, that it could be possible to use a Tg cutoff lower than $10 \mathrm{ng} / \mathrm{ml}$. Numerous studies show also that ${ }^{18}$ FDG PET/CT is not only a diagnostic technique, but can also assume considerable prognostic value, particularly in metastatic disease. FDG-PET positivity and low or absent iodine uptake reflect an aggressive cancer with a worse prognosis, reduced overall survival, and no response to ${ }^{131}$ I treatment $[69,70]$. 
Fig. 9 Molecular basis of dedifferentiation imaging (flipflop phenomenon)

(abbreviations: see text)

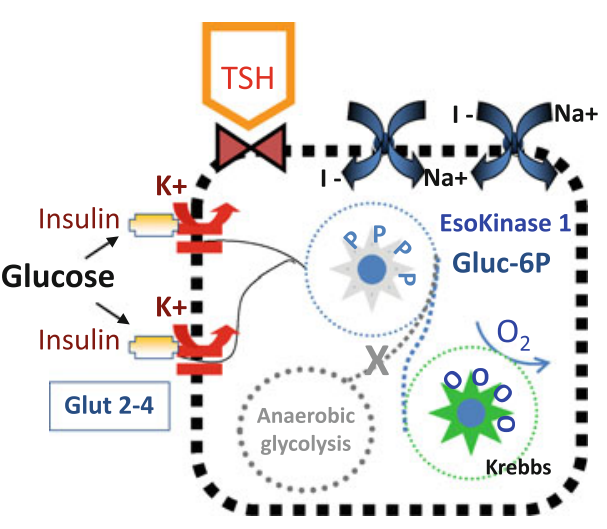

Normal thyroid cell

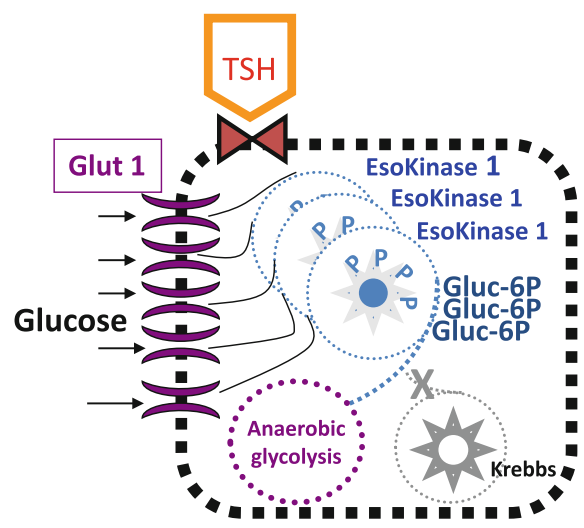

Thyroid tumor cell

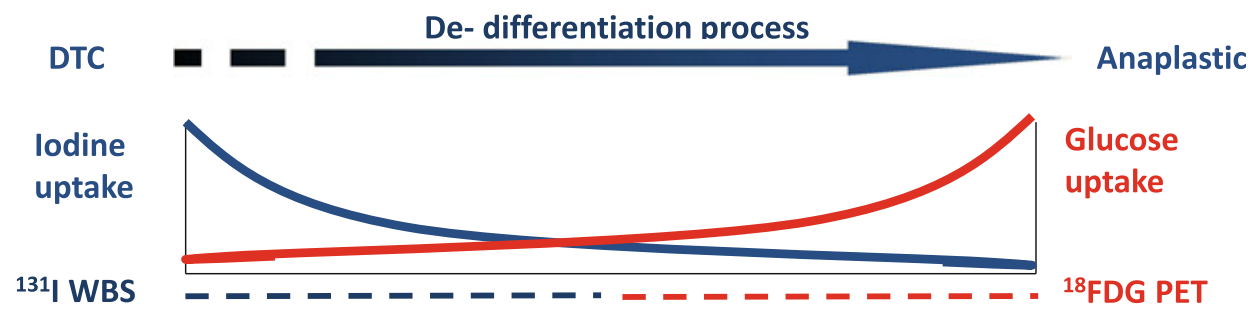

${ }^{18}$ FDG PET/CT is thus the method of choice for identifying patients with early progression who might benefit from new targeted therapies.

As regards response to treatment, PET/CT plays a primary role in assessing treatment effectiveness in patients refractory to iodine therapy. This application is based on new molecules now available that have a specific effect on different targets expressed by thyroid tumors, such as VEGF (vascular endothelial growth factor) receptor, BRAF, or RET/PTC [71]. The advantage is linked directly to the cytostatic action of these drugs which can therefore be used to assess late morphological changes as opposed to metabolic response, which is assessable early, using PET [72]. There are no consistent data regarding the actual effectiveness of FDG-PET after TSH stimulation with thyroid hormone withdrawal or after stimulation with rhTSH. As a consequence, rhTSH stimulation is not recommended in daily clinical practice before FDG PET/CT examinations [66].

The possibility of using ${ }^{124} \mathrm{I}$-PET/CT in pretreatment dosimetry, i.e., to quantify tumor volume for calculating the effective dose of ${ }^{131}$ I to be administered [73], has been explored, while another possibility is to use the technique to evaluate the extent of disease in cases of recurrence, as it is more sensitive than the diagnostic whole-body scanning [74]. ${ }^{124}$ I-PET/CT identifies patient with tumor-enhancing iodine who may benefit from ${ }^{31} \mathrm{I}$ therapy and patients refractory to treatment in whom unnecessary irradiation can be avoided.

\section{Flip-flop phenomenon}

The flip-flop phenomenon is the observation that thyroid cancers and their metastases show either some iodine uptake combined with low FDG uptake, or no uptake of ${ }^{131}$ I combined with high FDG uptake [75]. The expression flip-flop refers to the alternating pattern of ${ }^{131} \mathrm{I}$ and FDG uptake observed in well-differentiated PTCs or FTCs that have high I uptake and low FDG uptake, in comparison with PDTCs and ATCs, that have low I uptake and high FDG uptake (Fig. 9). Histologically, 2 to $5 \%$ of welldifferentiated thyroid tumors will lose their differentiation and become candidates for the "flip- flop" phenomenon [54]. The dedifferentiated tumors lose the morphological and genetic profile typical of well-differentiated lesions and become more aggressive. The histopathological features that accompany this progression are usually represented by increased mitotic activity, as shown by immunolabeling for Mib-1 antigen and by necrosis. Highly proliferative cells require high levels of energy, provided mainly by glucose; necrosis is a reflection of the rapidly increasing cells' inability to obtain sufficient energy and the impossibility of the growing tumors to create a welldeveloped vascular network, without which the cells die. Moreover, necrosis has been found to be a predictor of aggressive behavior [54]. The deregulation of NIS in poorly differentiated tumors coupled with a glucose transporter increases to support the proliferating cells' rapidly increasing demand for nutrients. GLUT-1 gene 
expression is also related to an unfavorable prognosis, as are PDTCs [50]. Glucose uptake seems also directly related, at least in vitro, to TSH [76-78].

Conflict of interest M. Bongiovanni, G. Paone, L. Ceriani, M. Pusztaszeri declare that they have no conflict of interest related to the publication of this article.

Human and Animal Studies This article does not contain any studies with human or animal subjects performed by the any of the authors.

\section{References}

1. Tan GH, Gharib H (1997) Thyroid incidentalomas: management approaches to nonpalpable nodules discovered incidentally on thyroid imaging. Ann Intern Med 126:226-231

2. Castro MR, Gharib H (2000) Thyroid nodules and cancer. When to wait and watch, when to refer. Postgrad Med 107:113-116, 119-120, 123-114

3. Xing M (2013) Molecular pathogenesis and mechanisms of thyroid cancer. Nat Rev Cancer 13:184-199

4. Howlader N, Noone A, M., Krapcho M, Neyman N, Aminou R, Altekruse SF, Kosary CL, Ruhl J, Tatalovich Z, Cho H, Mariotto A, Eisner MP, Lewis DR, Chen HS, Feuer EJ (2012) Cronin KA SEER Cancer Statistics Review, 1975-2009 (Vintage 2009 Populations), National Cancer Institute. Bethesda, MD. http://seer.cancer.gov/csr/1975_2009_pops09/, based on November 2011 SEER data submission, posted on the SEER website

5. Kim BS, Kim SJ, Kim IJ, Pak K, Kim K (2012) Factors associated with positive F-18 flurodeoxyglucose positron emission tomography before thyroidectomy in patients with papillary thyroid carcinoma. Thyroid 22:725-729

6. Faquin WC, Bongiovanni M, Sadow PM (2011) Update in thyroid fine needle aspiration. Endocr Pathol 22:178-183

7. Fletcher JW, Djulbegovic B, Soares HP, Siegel BA, Lowe VJ, Lyman GH, Coleman RE, Wahl R, Paschold JC, Avril N, Einhorn LH, Suh WW, Samson D, Delbeke D, Gorman M, Shields AF (2008) Recommendations on the use of 18F-FDG PET in oncology. J Nucl Med 49:480-508

8. Heston TF, Wahl RL (2010) Molecular imaging in thyroid cancer. Cancer Imaging 10:1-7

9. Hundahl SA, Cady B, Cunningham MP, Mazzaferri E, McKee RF, Rosai J, Shah JP, Fremgen AM, Stewart AK, Hölzer S (2000) Initial results from a prospective cohort study of 5583 cases of thyroid carcinoma treated in the United States during 1996. US and German Thyroid Cancer Study Group. An American College of Surgeons Commission on Cancer Patient Care Evaluation study. Cancer 89:202-217

10. Sahoo S, Hoda SA, Rosai J, DeLellis RA (2001) Cytokeratin 19 immunoreactivity in the diagnosis of papillary thyroid carcinoma: a note of caution. Am J Clin Pathol 116:696-702

11. Tuttle RM, Ball DW, Byrd D, Dilawari RA, Doherty GM, Duh QY, Ehya H, Farrar WB, Haddad RI, Kandeel F, Kloos RT, Kopp P, Lamonica DM, Loree TR, Lydiatt WM, McCaffrey JC, Olson JA, Parks L, Ridge JA, Shah JP, Sherman SI, Sturgeon C, Waguespack SG, Wang TN, Wirth LJ, Network NCC (2010) Thyroid carcinoma. J Natl Compr Canc Netw 8:1228-1274

12. Xing M (2007) BRAF mutation in papillary thyroid cancer: pathogenic role, molecular bases, and clinical implications. Endocr Rev 28:742-762
13. Nikiforov YE, Yip L (2013) Nikiforova MN (2013) New strategies in diagnosing cancer in thyroid nodules: impact of molecular markers. Clin Cancer Res 19(9):2283-2288. doi:10.1158/10780432.CCR-12-1253

14. Nikiforov YE, Ohori NP, Hodak SP, Carty SE, LeBeau SO, Ferris RL, Yip L, Seethala RR, Tublin ME, Stang MT, Coyne C, Johnson JT, Stewart AF, Nikiforova MN (2011) Impact of mutational testing on the diagnosis and management of patients with cytologically indeterminate thyroid nodules: a prospective analysis of 1056 FNA samples. J Clin Endocrinol Metab 96:3390-3397

15. Baker CH, Morris JC (2004) The sodium-iodide symporter. Curr Drug Targets Immune Endocr Metabol Disord 4:167-174

16. Carrasco N (1993) Iodide transport in the thyroid gland. Biochim Biophys Acta 1154:65-82

17. Kollecker I, von Wasielewski R, Langner C, Mueller JA, Spitzweg C, Kreipe H, Brabant G (2012) Subcellular distribution of the sodium-iodide-symporter (NIS) in benign and malignant thyroid tissues. Thyroid 22:529-535

18. Laperle KM, Kim DC, Hall NC, Bobbey A, Shen DH, Nagy R, Wakely Jr PE, Lehman A, Jarjoura D, Jhiang SM (2013) Modulation of sodium/iodide symporter expression in the salivary gland. Thyroid (epub ahead of print)

19. Dohán O, De la Vieja A, Paroder V, Riedel C, Artani M, Reed M, Ginter CS, Carrasco N (2003) The sodium/iodide Symporter (NIS): characterization, regulation, and medical significance. Endoc Rev 24:48-77

20. Chung JK, Lee YJ, Jeong JM, Lee DS, Lee MC, Cho BY, Koh CS (1997) Clinical significance of hepatic visualization on iodine131 whole-body scan in patients with thyroid carcinoma. J Nucl Med 38:1191-1195

21. Omür O, Akgün A, Ozcan Z, Sen C, Ozkiliç H (2009) Clinical implications of diffuse hepatic uptake observed in postablative and post-therapeutic I-131 scans. Clin Nucl Med 34:11-14

22. Oh JR, Ahn BC (2012) False-positive uptake on radioiodine whole-body scintigraphy: physiologic and pathologic variants unrelated to thyroid cancer. Am J Nucl Med Mol Imaging $2: 285-362$

23. Galrão AL, Sodré AK, Camargo RY, Friguglietti CU, Kulcsar MA, Lima EU, Medeiros-Neto G, Rubio IG (2013) Methylation levels of sodium-iodide symporter (NIS) promoter in benign and malignant thyroid tumors with reduced NIS expression. Endocrine 43:225-229

24. Xing M, Westra WH, Tufano RP, Cohen Y, Rosenbaum E, Rhoden KJ, Carson KA, Vasko V, Larin A, Tallini G, Tolaney S, Holt EH, Hui P, Umbricht CB, Basaria S, Ewertz M, Tufaro AP, Califano JA, Ringel MD, Zeiger MA, Sidransky D, Ladenson PW (2005) BRAF mutation predicts a poorer clinical prognosis for papillary thyroid cancer. J Clin Endocrinol Metab 90:6373-6379

25. Schmutzler C, Winzer R, Meissner-Weigl J, Kohrle J (1997) Retinoic acid increases sodium/iodide symporter mRNA levels in human thyroid cancer cell lines and suppresses expression of functional symporter in nontransformed FRTL-5 rat thyroid cells. Biochem Biophys Res Commun 240:832-838

26. Elisei R, Vivaldi A, Agate L, Ciampi R, Molinaro E, Piampiani P, Romei C, Faviana P, Basolo F, Miccoli P, Capodanno A, Collecchi P, Pacini F, Pinchera A (2005) All-trans-retinoic acid treatment inhibits the growth of retinoic acid receptor beta messenger ribonucleic acid expressing thyroid cancer cell lines but does not reinduce the expression of thyroid-specific genes. J Clin Endocrinol Metab 90:2403-2411

27. Simon D, Kohrle J, Schmutzler C, Mainz K, Reiners C, Roher HD (1996) Redifferentiation therapy of differentiated thyroid carcinoma with retinoic acid: basics and first clinical results. Exp Clin Endocrinol Diabetes 104(Suppl 4):13-15 
28. Gruning T, Tiepolt C, Zophel K, Bredow J, Kropp J, Franke WG (2003) Retinoic acid for redifferentiation of thyroid cancer-does it hold its promise? Eur J Endocrinol 148:395-402

29. Boerner AR, Petrich T, Weckesser E, Fricke H, Hofmann M, Otto D, Weckesser M, Langen KJ, Knapp WH (2002) Monitoring isotretinoin therapy in thyroid cancer using 18F-FDG PET. Eur J Nucl Med Mol Imaging 29:231-236

30. Courbon F, Zerdoud S, Bastie D, Archambaud F, Hoff M, Eche N, Berry I, Caron P (2006) Defective efficacy of retinoic acid treatment in patients with metastatic thyroid carcinoma. Thyroid 16:1025-1031

31. Handkiewicz-Junak D, Roskosz J, Hasse-Lazar K, Szpak-Ulczok S, Puch Z, Kukulska A, Olczyk T, Piela A, Paliczka-Cieslik E, Jarzab B (2009) 13-cis-retinoic acid re-differentiation therapy and recombinant human thyrotropin-aided radioiodine treatment of non-functional metastatic thyroid cancer: a single-center, 53-patient phase 2 study. Thyroid Res 2:8

32. Ho AL, Grewal RK, Leboeuf R, Sherman EJ, Pfister DG, Deandreis D, Pentlow KS, Zanzonico PB, Haque S, Gavane S, Ghossein RA, Ricarte-Filho JC, Dominguez JM, Shen R, Tuttle RM, Larson SM, Fagin JA (2013) Selumetinib-enhanced radioiodine uptake in advanced thyroid cancer. $\mathrm{N}$ Engl $\mathrm{J}$ Med 368:623-632

33. Lee YL, Lee YJ, Ahn SJ, Choi TH, Moon BS, Cheon GJ, Lee SW, Ahn BC, Ha JH, Lee J (2010) Combined radionuclidechemotherapy and in vivo imaging of hepatocellular carcinoma cells after transfection of a triple-gene construct, NIS, HSV1sr39tk, and EGFP. Cancer Lett 290:129-138

34. Hsieh YJ, Ke CC, Liu RS, Wang FH, Tang KT, Chi CW, Chen FD, Lee CH (2007) Radioiodide imaging and treatment of ARO cancer xenograft in a mouse model after expression of human sodium iodide symporter. Anticancer Res 27:2515-2522

35. Moretti JL, Hauet N, Caglar M, Rebillard O, Burak Z (2005) To use MIBI or not to use MIBI? That is the question when assessing tumour cells. Eur J Nucl Med Mol Imaging 32:836-842

36. Vattimo A, Bertelli P, Cintorino M, Burroni L, Volterrani D, Vella A (1995) Identification of Hurthle cell tumor by singleinjection, double-phase scintigraphy with technetium-99 m-sestamibi. J Nucl Med 36:778-782

37. Masood S, Auguste LJ, Westerband A, Belluco C, Valderama E, Attie J (1993) Differential oncogenic expression in thyroid follicular and Hurthle cell carcinomas. Am J Surg 166:366-368

38. Stojadinovic A, Ghossein RA, Hoos A, Urist MJ, Spiro RH, Shah JP, Brennan MF, Shaha AR, Singh B (2001) Hurthle cell carcinoma: a critical histopathologic appraisal. J Clin Oncol 19:2616-2625

39. DeLellis R, Lloyd R, Heitz P, Eng C (2004) Pathology and genetics of tumours of endocrine organs. World Health Organization Classification of Tumours. IARC Press, Lyon

40. Musholt PB, Musholt TJ, Morgenstern SC, Worm K, Sheu SY, Schmid KW (2008) Follicular histotypes of oncocytic thyroid carcinomas do not carry mutations of the BRAF hot-spot. World $\mathbf{J}$ Surg 32:722-728

41. Thompson NW, Dunn EL, Batsakis JG, Nishiyama RH (1974) Hurthle cell lesions of the thyroid gland. Surg Gynecol Obstet 139:555-560

42. Barnabei A, Ferretti E, Baldelli R, Procaccini A, Spriano G, Appetecchia M (2009) Hurthle cell tumours of the thyroid. Personal experience and review of the literature. Acta Otorhinolaryngol Ital 29:305-311

43. Evans HL, Vassilopoulou-Sellin R (1998) Follicular and Hurthle cell carcinomas of the thyroid: a comparative study. Am J Surg Pathol 22:1512-1520

44. Goldstein NS, Czako P, Neill JS (2000) Metastatic minimally invasive (encapsulated) follicular and Hurthle cell thyroid carcinoma: a study of 34 patients. Mod Pathol 13:123-130
45. Roh MH, Jo VY, Stelow EB, Faquin WC, Zou KH, Alexander EK, Larsen PR, Marqusee E, Benson CB, Frates MC, Gawande A, Moore FD Jr, Cibas ES (2011) The predictive value of the fine-needle aspiration diagnosis ,suspicious for a follicular neoplasm, hurthle cell type " in patients with hashimoto thyroiditis. Am J Clin Pathol 135:139-145

46. Spanu A, Schillaci O, Madeddu G (2005) 99mTc labelled cationic lipophilic complexes in malignant and benign tumors: the role of SPET and pinhole-SPET in breast cancer, differentiated thyroid carcinoma and hyperparathyroidism. Q J Nucl Med Mol Imaging 49:145-169

47. Del Vecchio S, Ciarmiello A, Salvatore M (1999) Clinical imaging of multidrug resistance in cancer. Q J Nucl Med 43:125-131

48. Bos R, van Der Hoeven JJ, van Der Wall E, van Der Groep P, van Diest PJ, Comans EF, Joshi U, Semenza GL, Hoekstra OS, Lammertsma AA, Molthoff CF (2002) Biologic correlates of (18)fluorodeoxyglucose uptake in human breast cancer measured by positron emission tomography. J Clin Oncol 20:379-387

49. Grabellus F, Nagarajah J, Bockisch A, Schmid KW, Sheu SY (2012) Glucose transporter 1 expression, tumor proliferation, and iodine/glucose uptake in thyroid cancer with emphasis on poorly differentiated thyroid carcinoma. Clin Nucl Med 37:121-127

50. Schönberger J, Rüschoff J, Grimm D, Marienhagen J, Rümmele P, Meyringer R, Kossmehl P, Hofstaedter F, Eilles C (2002) Glucose transporter 1 gene expression is related to thyroid neoplasms with an unfavorable prognosis: an immunohistochemical study. Thyroid 12:747-754

51. Younes M, Brown RW, Mody DR, Fernandez L, Laucirica R (1995) GLUT1 expression in human breast carcinoma: correlation with known prognostic markers. Anticancer Res 15: 2895-2898

52. Avril N, Menzel M, Dose J, Schelling M, Weber W, Jänicke F, Nathrath W, Schwaiger M (2001) Glucose metabolism of breast cancer assessed by 18F-FDG PET: histologic and immunohistochemical tissue analysis. J Nucl Med 42:9-16

53. Brown RS, Wahl RL (1993) Overexpression of Glut-1 glucose transporter in human breast cancer. An immunohistochemical study. Cancer 72:2979-2985

54. Rivera M, Ghossein RA, Schoder H, Gomez D, Larson SM, Tuttle RM (2008) Histopathologic characterization of radioactive iodine-refractory fluorodeoxyglucose-positron emission tomography-positive thyroid carcinoma. Cancer 113:48-56

55. Phelps ME (2000) Positron emission tomography provides molecular imaging of biological processes. Proc Natl Acad Sci USA 97:9226-9233

56. Hoekstra CJ, Paglianiti I, Hoekstra OS, Smit EF, Postmus PE, Teule GJ, Lammertsma AA (2000) Monitoring response to therapy in cancer using [18F]-2-fluoro-2-deoxy-D-glucose and positron emission tomography: an overview of different analytical methods. Eur J Nucl Med 27:731-743

57. Thorens B (1993) Facilitated glucose transporters in epithelial cells. Annu Rev Physiol 55:591-608

58. Pauwels EK, Ribeiro MJ, Stoot JH, McCready VR, Bourguignon M, Mazière B (1998) FDG accumulation and tumor biology. Nucl Med Biol 25:317-322

59. Hooft L, van der Veldt AA, van Diest PJ, Hoekstra OS, Berkhof J, Teule GJ, Molthoff CF (2005) [18F]fluorodeoxyglucose uptake in recurrent thyroid cancer is related to hexokinase $\mathrm{i}$ expression in the primary tumor. J Clin Endocrinol Metab 90:328-334

60. Durante C, Puxeddu E, Ferretti E, Morisi R, Moretti S, Bruno R, Barbi F, Avenia N, Scipioni A, Verrienti A, Tosi E, Cavaliere A, Gulino A, Filetti S, Russo D (2007) BRAF mutations in papillary thyroid carcinomas inhibit genes involved in iodine metabolism. J Clin Endocrinol Metab 92:2840-2843 
61. Palmedo H, Bucerius J, Joe A, Strunk H, Hortling N, Meyka S, Roedel R, Wolff M, Wardelmann E, Biersack HJ, Jaeger U (2006) Integrated PET/CT in differentiated thyroid cancer: diagnostic accuracy and impact on patient management. J Nucl Med 47:616-624

62. Shammas A, Degirmenci B, Mountz JM, McCook BM, Branstetter B, Bencherif B, Bencherif BB, Joyce JM, Carty SE, Kuffner HA, Avril N (2007) 18F-FDG PET/CT in patients with suspected recurrent or metastatic well-differentiated thyroid cancer. J Nucl Med 48:221-226

63. Mirallié E, Guillan T, Bridji B, Resche I, Rousseau C, Ansquer C, Bodet-Milin C, Curtet C, Carnaille B, Murat A, Charbonnel B, Kraeber-Bodéré F (2007) Therapeutic impact of 18FDG-PET/CT in the management of iodine-negative recurrence of differentiated thyroid carcinoma, Surgery 142:952-958 (discussion 952-958)

64. Pryma DA, Schöder H, Gönen M, Robbins RJ, Larson SM, Yeung HW (2006) Diagnostic accuracy and prognostic value of 18F-FDG PET in Hürthle cell thyroid cancer patients. J Nucl Med 47:1260-1266

65. Vander Heiden MG, Cantley LC, Thompson CB (2009) Understanding the Warburg effect: the metabolic requirements of cell proliferation. Science 324:1029-1033

66. Cooper DS, Doherty GM, Haugen BR, Kloos RT, Lee SL, Mandel SJ, Mazzaferri EL, McIver B, Pacini F, Schlumberger M, Sherman SI, Steward DL, Tuttle RM (2009) Revised American Thyroid Association management guidelines for patients with thyroid nodules and differentiated thyroid cancer. Thyroid 19:1167-1214

67. Giovanella L, Ceriani L, De Palma D, Suriano S, Castellani M, Verburg FA (2012) Relationship between serum thyroglobulin and 18FDG-PET/CT in 131I-negative differentiated thyroid carcinomas. Head Neck 34:626-631

68. Vera P, Kuhn-Lansoy C, Edet-Sanson A, Hapdey S, Modzelewski R, Hitzel A, d'Anjou J, Basuyau JP (2010) Does recombinant human thyrotropin-stimulated positron emission tomography with [18F]fluoro-2-deoxy-D-glucose improve detection of recurrence of well-differentiated thyroid carcinoma in patients with low serum thyroglobulin? Thyroid 20:15-23

69. Robbins RJ, Wan Q, Grewal RK, Reibke R, Gonen M, Strauss HW, Tuttle RM, Drucker W, Larson SM (2006) Real-time prognosis for metastatic thyroid carcinoma based on $2-[18 \mathrm{~F}]$ fluoro-2-deoxy-D-glucose-positron emission tomography scanning. J Clin Endocrinol Metab 91:498-505

70. Lazar V, Bidart JM, Caillou B, Mahé C, Lacroix L, Filetti S, Schlumberger M (1999) Expression of the $\mathrm{Na}^{+} / \mathrm{I}^{-}$symporter gene in human thyroid tumors: a comparison study with other thyroid-specific genes. J Clin Endocrinol Metab 84:3228-3234

71. Prior JO, Montemurro M, Orcurto MV, Michielin O, Luthi F, Benhattar J, Guillou L, Elsig V, Stupp R, Delaloye AB, Leyvraz $S$ (2009) Early prediction of response to sunitinib after imatinib failure by $18 \mathrm{~F}$-fluorodeoxyglucose positron emission tomography in patients with gastrointestinal stromal tumor. J Clin Oncol $27: 439-445$

72. Schlumberger M, Network FT (2011) Targeted therapy in refractory thyroid cancer. Eur J Cancer 47(Suppl 3):S328-S329

73. Sgouros G, Kolbert KS, Sheikh A, Pentlow KS, Mun EF, Barth A, Robbins RJ, Larson SM (2004) Patient-specific dosimetry for 131I thyroid cancer therapy using 124I PET and 3-dimensionalinternal dosimetry (3D-ID) software. J Nucl Med 45:1366-1372

74. Phan HT, Jager PL, Paans AM, Plukker JT, Sturkenboom MG, Sluiter WJ, Wolffenbuttel BH, Dierckx RA, Links TP (2008) The diagnostic value of 124I-PET in patients with differentiated thyroid cancer. Eur J Nucl Med Mol Imaging 35:958-965

75. Grünwald F, Schomburg A, Bender H, Klemm E, Menzel C, Bultmann T, Palmedo H, Ruhlmann J, Kozak B, Biersack HJ (1996) Fluorine-18 fluorodeoxyglucose positron emission tomography in the follow-up of differentiated thyroid cancer. Eur J Nucl Med 23:312-319

76. Filetti S, Damante G, Foti D (1987) Thyrotropin stimulates glucose transport in cultured rat thyroid cells. Endocrinology 120:2576-2581

77. Khan N, Oriuchi N, Higuchi T, Zhang H, Endo K (2003) PET in the follow-up of differentiated thyroid cancer. $\mathrm{Br} \mathrm{J}$ Radiol 76:690-695

78. Hosaka Y, Tawata M, Kurihara A, Ohtaka M, Endo T, Onaya T (1992) The regulation of two distinct glucose transporter (GLUT1 and GLUT4) gene expressions in cultured rat thyroid cells by thyrotropin. Endocrinology 131:159-165 